\title{
Short Term Leguminous Trees-Tillage Interactions and Their Effect on Soil-Water Content in a Semi-Arid Agroforestry Parkland
}

\author{
Chester Kalinda ${ }^{1,2 *}$, David Mburu${ }^{1}$, Kamau Ngamau', Lwali A. Chisala², Donald Zulu², \\ John Kihoro ${ }^{1}$ \\ ${ }^{1}$ Jomo Kenyatta University of Agriculture and Technology, Nairobi, Kenya \\ ${ }^{2}$ The Copperbelt University, Kitwe, Zambia \\ Email: ${ }^{*}$ ckalinda@gmail.com
}

Received 10 July 2015; accepted 19 September 2015; published 22 September 2015

Copyright (C) 2015 by authors and Scientific Research Publishing Inc.

This work is licensed under the Creative Commons Attribution International License (CC BY).

http://creativecommons.org/licenses/by/4.0/

c) (i) Open Access

\begin{abstract}
Agricultural activities that encourage slashing, burning and ploughing greatly affect the soil structure and soil organic matter on which soil water retention depends. In this study, we hypothesized that inclusion of rotational leguminous tree species improves soil water retention in a semi-arid conservation agriculture system. In a study done in Kibwezi, semi-arid eastern Kenya, results showed that the amount of water retained in the different soil strata from plots with different tree species and tillage practices was highly significant $(P=0.032)$. Plots with planting basins and Gliricidia sepium and Faidherbia albida tree species retained more water in both the upper and lower strata. Plots with $G$. sepium tree species under planting basins and zero tillage under $F$. albida had significantly higher soil organic carbon levels than plots that were managed under ridges and ploughing $(P=0.002)$. On the other hand, bulk density in plots with planting basins and zero tillage and ridges ranged between $1.35 \mathrm{~g} / \mathrm{cm}^{3}$ and $1.53 \mathrm{~g} / \mathrm{cm}^{3}$. Conventional tillage plots had bulk density values of $1.65 \mathrm{~g} / \mathrm{cm}^{3}$ and $1.72 \mathrm{~g} / \mathrm{cm}^{3}$ in the upper and lower strata respectively. The timedependent nature of rotational leguminous tree species on soil organic matter and soil water retention in the semi-arid conservation agriculture system highlights the importance of considering these species for improving organic carbon and water retention for improved crop production.
\end{abstract}

\section{Keywords}

G. sepium, F. albida, T. candida, Leguminous Tree Species, Soil Organic Carbon, Soil Water Retention, Infiltration

\footnotetext{
${ }^{*}$ Corresponding author.
}

How to cite this paper: Kalinda, C., Mburu, D., Ngamau, K., Chisala, L. A., Zulu, D., \& Kihoro, J. (2015). Short Term Leguminous Trees-Tillage Interactions and Their Effect on Soil-Water Content in a Semi-Arid Agroforestry Parkland. Open Journal of Forestry, 5, 668-677. http://dx.doi.org/10.4236/ojf.2015.57059 


\section{Introduction}

Soil and water losses are becoming a major challenge to smallholder farmers. Declining crop yields and increasing levels of food insecurity especially among the smallholder farmers in the arid and semi-arid regions have been blamed on increased soil and water losses (Hernanz et al., 2002). The scarcity of water in the arid and semi-arid regions and now in the humid tropics where poor rainfall distribution leads to low moisture availability to plants thereby inducing water stress limits agricultural production (Osuji et al., 2010; Wild, 1984). Smallholder farming areas in semi-arid regions are low in soil organic matter and this makes the soil to have low soil structural stability, soil fertility and hydraulic properties (Lal, 2002) leading to water losses through runoff and reduction in the amount of water that infiltrates into the soil (Rao et al., 1998).

Many smallholder farmers use different tillage practices for land preparation. Chivenge et al. (2007) point out that tillage plays a significant part in influencing nutrient storage and release from soil organic matter. However, some of these practices lead to the break down in soil organic carbon and destruction of the soil structure resulting in increased runoff and soil and water losses (Nyamadzawo et al., 2008; Thierfelder \& Wall, 2009). Deterioration in the structure of the soil can have both short and long term effects on the soil organic matter which in turn will affect soil water content, retention and plant growth. Soil organic matter represents a major proportion of the organic carbon within the terrestrial biosphere which plays an important role in soil fertility (Powlson et al., 2001) and affects infiltration, water retention, crop growth and productivity (Cattanio, 2012; Imogie et al., 2008). In view of the foregoing, it is important that higher rain use efficiency be achieved so that the infiltration rate of the soil is increased to diminish losses of water through runoff (Gicheru et al., 2004).

Soil water content is an important hydraulic property related to size and connectedness of pore spaces (Tuller $\&$ Or, 2004). Disruption of the soil structure and breakdown of soil constituents like organic matter highly affect soil moisture content. Studies (Li et al., 2009; Meskini et al., 2014) have shown that the mineral composition and pore network geometry of many soils are different and that these can affect soil water retention (Li et al., 2009). The use of ploughing as the major tillage practice in the semi-arid area of eastern Kenya affects the soil structure, organic matter and soil water retention.

Water scarcity is a major problem constraining agricultural production in the semi-arid area of Kibwezi. To effectively make use of the limited rainfall received in the semi-arid areas, it's important to put in place and adopt soil management practices and tillage methods that enhance rain water penetration into the soil and ensure that adequate water is conserved for plant growth. Therefore, a good understanding of the links between the tillage systems and the soil water retention is needed especially in the arid and semi-arid region for improved soil water retention.

Decline in soil productivity has led to development of new methods that can sustain crop production and productivity (Cattanio, 2012). There is evidence that woody leguminous tree species can be used to produce biomass and recycle nutrients in agroforestry systems, thus hastening soil fertility restoration (Imogie et al., 2008). Leguminous trees have beneficial effects on the soil physical and chemical properties, soil moisture content and retention by their litter deposition, root activity and changes in microclimate brought about by the leaf canopy (Arowolo, 2007; Cattanio, 2012). Notwithstanding these benefits, the use of short term rotational leguminous tree species in a conservation agriculture system of the semi-arid regions of Kenya is little known. This study was therefore carried out to investigate the effect of short term rotational leguminous tree species on soil water retention in a semi-arid conservation agriculture system. In this study, we hypothesized that short term leguminous tree species greatly improve water retention in both the lower and upper soil strata and improve soil bulky density through their influence on soil organic matter in a semi-arid conservation agriculture agroforestry system.

\section{Materials and Methods}

\subsection{Site Description}

This study was conducted at Masongaleni location which is about $22 \mathrm{~km}$ south-east of Kibwezi town in eastern Kenya. The area falls in a semi-arid zone and experiences a bimodal pattern of rainfall; with the long rains falling in March to May and short rains in October to December (Nyariki et al., 2004). The short rains are more reliable for crop production than the long rains. The rain received during the long rain season is erratic and unreliable. In total, the area receives less than $500 \mathrm{~mm}$ of rainfall per annum (Nyariki et al., 2004). Mean tempera- 
tures range from $20.2^{\circ} \mathrm{C}$ to $24.6^{\circ} \mathrm{C}$ but temperatures as high as $32^{\circ} \mathrm{C}$ have been recorded during prolonged drought periods.

The major land forms include the volcanic Chyulu Hills, which lies along the southwest border of the county in Kibwezi. The altitude ranges from $600 \mathrm{~m}$ above sea level to $1900 \mathrm{~m}$. The topography greatly influences the precipitation (Biamah, 2005).

\subsection{Soil Types and Farming Systems}

The most dominant soils in the area are the lixisols and Acrisols according to FAO/UNESCO Classification (Biamah, 2005). These soils are acidic, with low organic matter, low in water retention capacity and have strong surface sealing and crusting properties (Biamah et al., 1993; Jaetzold et al., 2006). The majority of farmers are small holder and use hand hoes and animal draw ploughs for land preparation. The crops grown are maize, cow peas, beans, pigeon peas and green grams (Biamah, 2005).

\subsection{Vegetation}

The distribution of vegetation is affected by a number of complex interrelated factors such as climate, geological formation, soil types and the presence or absence of water (Nyariki et al., 2004). The natural vegetation is woodland and savanna, with several tree species mainly Acacia spp. such as Acacia tortilis (Forsk) and Acacia mellifera (Vahl.), Commiphora africana (A. Rich), Adansonia digitata Linn and Tamarindus indica L. Shrubs include Apis mellifera, Apis senegal (L.) and Grewia sp (Nyangito et al., 2009).

\subsection{Experimental Design and Layout}

The experimental design was a randomized complete block design (RCBD) with three replicates of the treatment combinations. The treatments comprised of four tillage practices namely: planting basins, zero tillage, ridges and ploughing and three tree species: Gliricidia sepium [Kunth], Tephrosia candida DC and Faidherbia albida [Delile A. chev] which wereplanted in October 2009 in plots measuring $20 \mathrm{~m} \times 20 \mathrm{~m}$ in the study site. This study was conducted between the months of February and August in 2012. Nine (9) farms located in three locations were selected. Three farms per locations were used in the study.

Three tillage practices, minimum tillage, zero tillage and ridges had a plot with one single tree species, replicated thrice. Gliricidia sepium and Tephrosia candida were planted at $2 \mathrm{~m} \times 1 \mathrm{~m}$ spacing. With proper maintenance of these trees during their growth and at coppicing, this spacing results in tree population of 5000 trees $\cdot \mathrm{ha}^{-1}$. At the time of the study, not all plots had this plant population. Tree head count recorded $60 \%-80 \%$ tree stand in the selected farms. Faidherbia albida trees were planted at $5 \mathrm{~m} \times 5 \mathrm{~m}$ giving plant density of 200 trees per hectare. G. sepium was coppiced once a year to a height of $50 \mathrm{~cm}$ above the ground just before the onset of the short rain season while light pruning of $T$. candida was done to avoid re-growth problems because the species is not known to regrow after cutting.

Rectangular shaped planting basins with a length of about $30-35 \mathrm{~cm}$ and width of about $10-12 \mathrm{~cm}$ (based on the width of the hoes that were used during land preparation) were prepared using hand hoesto a depth of about $20-25 \mathrm{~cm}$. This depth was used to help break any compacted soil layers below the surface. The basins were made in rows spaced at $70 \mathrm{~cm}(0.7 \mathrm{~m})$ between rows and $50 \mathrm{~cm}(0.5 \mathrm{~m})$ between basins in each row giving a total of 1143 planting basins in a $20 \mathrm{~m} \times 20 \mathrm{~m}$. Under zero-tillage, no soil disturbance was done during planting. The seeds were drilled directly into the soil using machetes or pangas. In the plots under conventional tillage, the crop residue from the previous season was gathered and burned. The plots were then ploughed. In plots with planting basins and zero tillage, crop residue and coppiced legume tree biomass were returned on the ground as mulch. Ridges were constructed using hand hoes by splitting the ridges from the previous season. This is because farmers have always used ridges in their field from one season to another for improved soil moisture retention and erosion control, especially where ridge height was well maintained. Plant residue and coppiced tree biomass were incorporated under the new ridge.

The coppicing of trees was done just before the onset of the more reliable short rains of October-November farming season. The trees were coppiced to about $50 \mathrm{~cm}$ height to allow for re-growth. Light coppicing of the over grown trees was done just before the onset of the March-April long rain season. However, to allow for more biomass accumulation, coppicing was done once a year. The selected farms had been doing this from the time the plots were established in 2009. 


\subsection{Soil Organic Carbon Determination}

Soil samples for total organic carbon determination were collected from quadrants of about $100 \mathrm{~m}^{2}$ drawn in each plot. The soil samples were collected randomly from three points within each quadrant. The sampling depth was $0-30 \mathrm{~cm}$. The soil samples collected were used to constitute a composite sample from which three soil samples were then taken and analyzed for total organic carbon using the Walkley \& Black (1934) rapid titration method.

\subsection{Determination of Soil Moisture Content}

Determination of soil moisture content was done using undisturbed soil samples which had been collected in metal cores of size $5 \mathrm{~cm} \times 2.5 \mathrm{~cm}$ and taken to the laboratory for analysis. Three soil samples per depth $(0-20$ $\mathrm{cm}, 20-30 \mathrm{~cm}$ ) were collected from each plot. In the laboratory, the samples were saturated with water from the bottom of the tray for 24 hours. The saturated samples were then allowed to drain out excess water for about 30 minutes to reach equilibrium of field capacity. These samples were then weighed and placed in a centrifugal chamber of the $\mathrm{pF}$ meter. Starting with the lowest tension, the machine was run for at least an hour. The samples were then removed, weighed and retained in the machine for the next tension level. The difference in weight represented the amount of water released within the specific range of revolutions/minute. The process was repeated at different revolutions per minute until the tension equivalent to wilting point was reached. The samples were then taken and dried in the oven at $105^{\circ} \mathrm{C}$ for at least 24 hours. The oven dry weight of the samples was obtained and the percentage moisture content and bulk density for all samples was computed.

The equivalent $\mathrm{pF}$ according to the range of revolutions was obtained using the following formulae:

$$
p F=2 \log n+\log h+\left(r+\frac{h}{2}\right)-4.95
$$

where: $n=$ number of revolutions;

$r=$ radius of sample;

$h=$ height of sample.

The selected range of revolutions per minute and the $\mathrm{pF}$ equivalent are given in Table 1 . The $\mathrm{pF}$ values were then plotted against the volumetric water content to obtain moisture characteristic curves. Moisture characteristic curves for the soils under the three tillage practices and different tree species were produced.

\subsection{Data Analysis}

To evaluate the effect of tree species and tillage practices on soil organic matter, we tested for variances differences using a two way ANOVA. Our interest was to evaluate the interaction between the tree species and the different tillage practices on soil organic matter. To test our hypotheses about the influence of short term leguminous tree species on water retention, we analysed our moisture retention results from the $\mathrm{pF}$ machine in a two way ANOVA and plotted moisture retention curves. We also subjected our results on bulky density under different leguminous trees and tillage practices to ANOVA tests. For separation of means, post hoc analysis was done using Least Square Differences (LSD) because this was a planned experiment. All these tests were done in Genstat $13^{\text {th }}$ Edition after testing for normality and constant variance.

Table 1. Revolutions per minute ( $\mathrm{rpm})$ versus $\mathrm{pF}$ equivalent in the centrifugal $\mathrm{pF}$ meter.

\begin{tabular}{ccc}
\hline Selected revolutions per minute $(\mathrm{rpm})$ & $P$ F value & Corresponding tension $(\mathrm{KPa})$ \\
\hline 500 & 1.72 & 5 \\
700 & 2.01 & 10 \\
1200 & 2.48 & 30 \\
2200 & 3.01 & 102 \\
3100 & 3.30 & 591 \\
4900 & 3.70 & 891 \\
6500 & 3.95 & 1585 \\
\hline
\end{tabular}




\section{Results}

\subsection{Soil Organic Carbon}

The amount of soil organic carbon (SOC) was highly influenced by the interaction of the tree species and tillage practices (Table 2). Plots with planting basins and zero tillage had significantly $(P=0.002)$ higher soil organic carbon levels than plots that were managed under ridges and ploughing.

\subsection{Soil Moisture Characteristic Curves}

Results from this study show that there were significant $(P=0.032)$ differences in the amount of water retained in the different soils from plots with different tree species and tillage practices. The best performing plots in terms of water retention were plots with G. sepium and F. albida tree species. $T$. candida was relatively better than the conventional plots. The available soil water for crop growth under minimum tillage plots with $G$. sepium and F. albida tree species was $5.8 \%$ and $6.2 \%$ respectively in the top strata $(0-20 \mathrm{~cm}$ depth) (Figure 1(a)). In the lower strata $(20-30 \mathrm{~cm}$ depth), the available soil water for crop growth under minimum tillage with $G$. sepium tree species was $6.0 \%$ while that under F. albida was $6.2 \%$ (Figure $1(b)$ ). Under conventional tillage practice, the available soil water for plant growth $3.6 \%$ in the top strata (Figure 1(a)) and $3.9 \%$ in the bottom strata (Figure 1(b)).

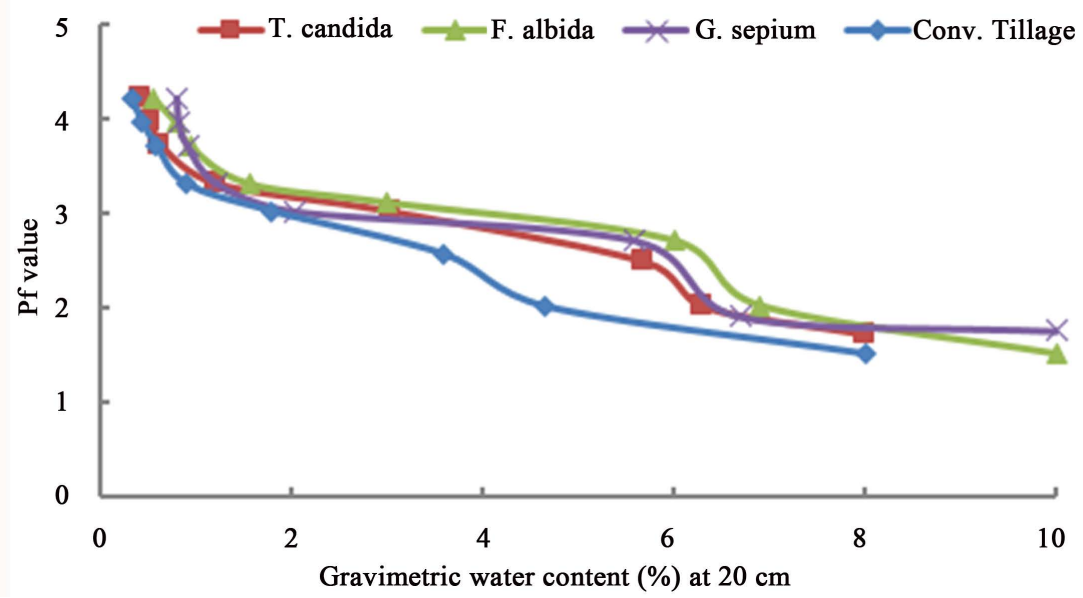

(a)

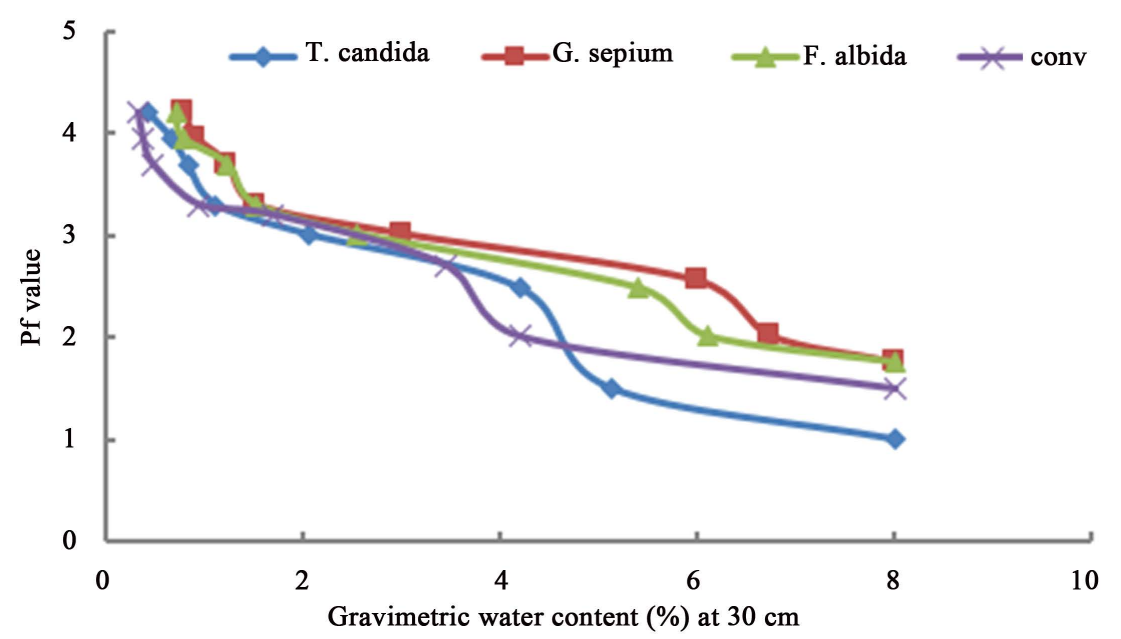

(b)

Figure 1. Moisture characteristic curves in minimum tillage practices plots: (a) at $20 \mathrm{~cm}$ depth; (b) at $30 \mathrm{~cm}$ depth. 
In zero tillage plots, water retention was highest in plots with $F$. albida and $T$. candida. The available soil water for crop growth under zero tillage with G. sepium tree species was $6.3 \%$ in the top strata (Figure 2(a)) and $5.2 \%$ in the lower strata. F. albida and T. candida had 5.8\% and 5.4\% respectively in the top strata (Figure 2(a)) and about 5.3\% and 3.8\% respectively in the lower strata (Figure 2(b)). Under conventional tillage, the available soil water was $3.7 \%$ in the top strata (Figure 2(a)), 3.5\% in the bottom strata (Figure 2(b)). Zero tillage plots with G. sepium tree species stored more water than the other two tree species with the same tillage practice.

Plots with ridges that had $T$. candida and G. sepium tree species had more water retained as compared to plots with $F$. albida and conventional tillage plots. The available soil water for crop growth under $T$. candida and $G$. sepium tree species was 5.8\% top strata and $4.8 \%$ in the lower strata (Figure 3(b)).

\subsection{Bulk Density}

Planting basins, zero tillage and ridges under the different tree species had bulk densities with typical values between $1.35 \mathrm{~g} / \mathrm{cm}^{3}$ and $1.60 \mathrm{~g} / \mathrm{cm}^{3}$ (Table 3). The least bulk density was observed in plots with G. sepium and

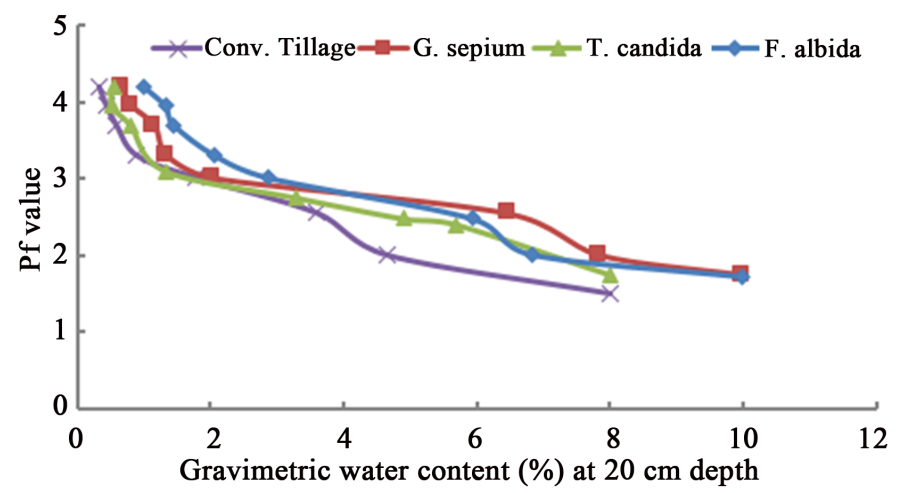

(a)

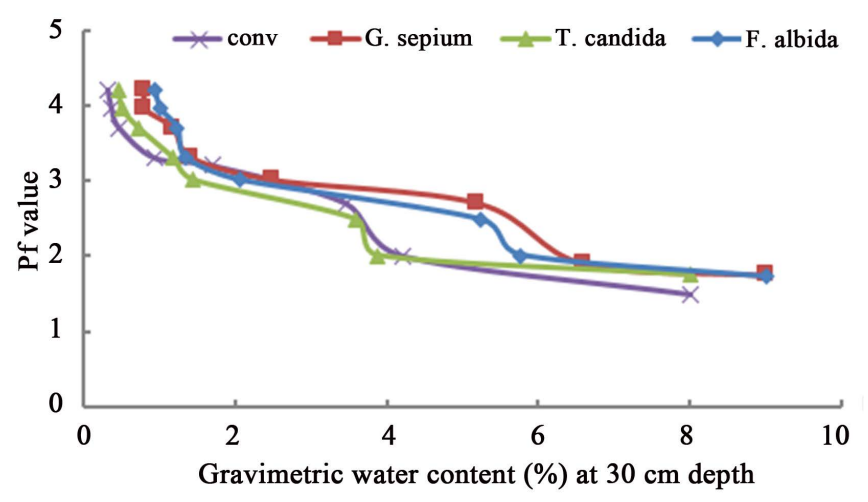

(b)

Figure 2. Moisture characteristic curves in zero tillage practices plots (a) at $20 \mathrm{~cm}$ depth; (b) at $30 \mathrm{~cm}$ depth.

Table 2. Influence of the interaction between tree species and tillage on soil organic carbon $\%(0-30 \mathrm{~cm})$.

\begin{tabular}{cccc}
\hline Tillage & \multicolumn{3}{c}{ Tree species } \\
\cline { 2 - 4 } & Gliricidia sepium & Tephrosia candida & Faidherbia albida \\
\hline Planting basins & $1.30^{\mathrm{a}, \mathrm{x}}$ & $1.23^{a, x}$ & $1.28^{b, x}$ \\
Zero tillage & $1.33^{a, x}$ & $1.12^{a b, y}$ & $1.35^{a, x}$ \\
Ridges & $1.14^{b, x}$ & $1.01^{b, y}$ & $1.11^{c, x y}$ \\
Ploughing & & 0.81 & \\
\hline
\end{tabular}

Superscripts letters $a, b$ and $c$ down the column compares same tree species under different tillage practices while letters $x, y$ and $z$ along the row compares same tillage practice but under different tree species. LSD 0.12 valued used to separate means. 


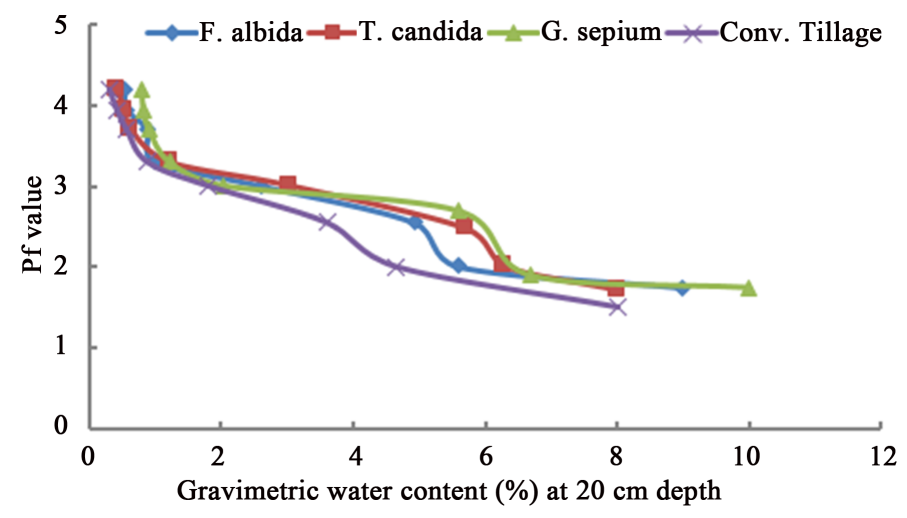

(a)

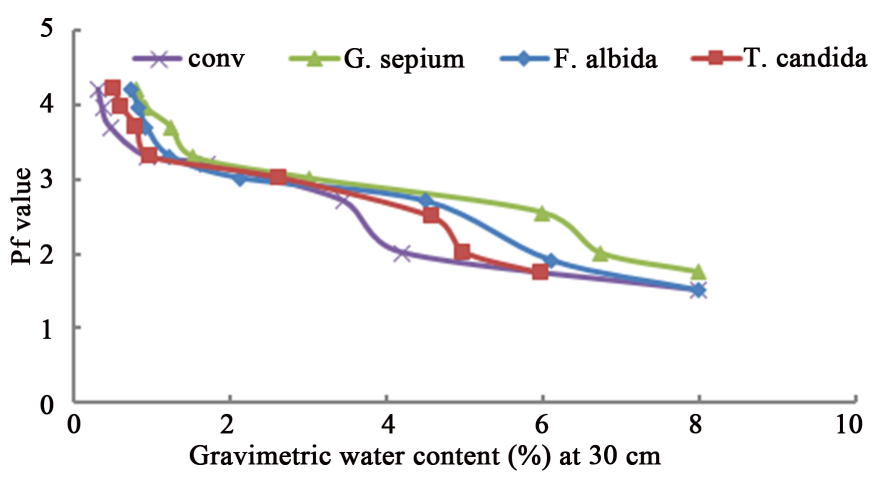

(b)

Figure 3. Moisture Characteristic curves in plots with ridges at $30 \mathrm{~cm}$ depth (a) at $20 \mathrm{~cm}$ depth; (b) at $30 \mathrm{~cm}$ depth.

Table 3. Bulk density of Kibwezi soil $(0-30 \mathrm{~cm})$ under different tillage practices.

\begin{tabular}{ccccccc}
\hline \multirow{2}{*}{ Tillage } & \multicolumn{3}{c}{ Bulk density $(0-20 \mathrm{~cm}) \mathrm{g} / \mathrm{cm}^{3}$} & \multicolumn{3}{c}{ Bulk density $(20-30 \mathrm{~cm}) \mathrm{g} / \mathrm{cm}^{3}$} \\
\cline { 2 - 7 } & F. albida & T. candida & G. sepium & F. albida & T. candida & G. sepium \\
Basins & 1.38 & 1.43 & 1.30 & 1.43 & 1.48 & 1.35 \\
Zero tillage & 1.45 & 1.48 & 1.33 & 1.5 & 1.53 & 1.38 \\
Ridges & 1.51 & 1.46 & 1.51 & 1.58 & 1.53 & 1.6 \\
Conventional tillage & & 1.65 & & & 1.75 &
\end{tabular}

planting basins. Under conventional tillage plots, high bulk density values of $1.65 \mathrm{~g} / \mathrm{cm}^{3}$ and $1.72 \mathrm{~g} / \mathrm{cm}^{3}$ in the upper and lower strata respectively were observed.

\section{Discussion}

\subsection{Organic Carbon}

Under G. sepium tree cropping system, zero tillage and planting basins practices had higher total organic carbon than plots that were ploughed. Gliricidia sepium had mean soil organic carbon of $1.195 \%$ across all tillage practices and was the best performing legume tree species in terms of soil organic carbon build up with frequent coppicing. The kind of tillage practices employed in land preparation can have an effect on soil organic carbon consequently affecting the soil structural stability, soil erosion, nutrient availability and nutrient loss. The rotational leguminous tree species that were included in conservation agriculture system positively influenced the soil by returning the leafy organic material to the soil. This decomposed to influence the physicochemical, nutritional, and biological properties of the soils (Diaz et al., 2004). The decomposed organic material contributed to 
soil organic carbon which positively influenced soil fertility, soil water content and infiltration. The inclusion of short term rotational leguminous tree species in the farming system increases the soil organic carbon and soil infiltration and retention. Salazar et al. (2011) observed that agroforestry has a positive effect on nutrient stocks and soil structure in the upper soil layer than the other crop management systems. Under conventional tillage plots, the crop residues were removed and hastened the decline of soil organic carbon (Mann et al., 2002). Plots with planting basins and zero tillage had the highest soil organic carbon content recording $1.27 \%$ and $1.26 \%$ respectively while the ploughed plots had the least amount.

\subsection{Soil Moisture Characteristic Curves}

Based on the differences in the amount of moisture retained at the soil samples, among the tillage and tree species combinations, significant $(P=0.032)$ differences in the soil water content were observed. The soil-water characteristic curves show that at low suction values, soil samples had a higher water-holding capacity.

Minimum tillage plots with G. sepium and F. albida tree species had more water compared to plots with $T$. candida and conventional tillage plots in both the lower and upper soil stratas. In zero tillage plots, the water retention in the upper strata was highest in plots with $F$. albida and $T$. candida while the in the lower strata, the retention was highest in plots with G. sepium and F. albida. Studies (Vanapalli et al., 1999; Zhou \& Yu, 2005) have shown that soil water characteristic curve depends on several factors such as soil structure, texture and compaction. The presence of tree leaf biomass and crop residue in plots maintained under minimum tillage, zero tillage and ridges led to improved soil texture, low bulky density, a higher infiltration rate and increased moisture retention. This is due to increase in the amount of organic matter content from the tree biomass and crop residue in the soil

\subsection{Bulk Density}

Plots with planting basins, zero tillage and ridges under the different tree species had bulk densities with typical values between $1.30 \mathrm{~g} / \mathrm{cm}^{3}$ and $1.60 \mathrm{~g} / \mathrm{cm}^{3}$ (Table 3). The least bulk density was observed in plots with $G$. sepium with basins in both the upper and lower strata. In plots with ridges, it was observed that the soils under the ridge (20 - $30 \mathrm{~cm}$ depth) were highly compacted thus likely to limit and restrict water movements. Because ridges are constructed and moved from season to seasons, the area on which the ridges had been previously constructed also exhibited high bulk density. Under conventional tillage plots, high bulk density values of 1.65 $\mathrm{g} / \mathrm{cm}^{3}$ and $1.75 \mathrm{~g} / \mathrm{cm}^{3}$ in the upper and lower strata respectively were observed. Increase in the bulk density decreases the volume occupied by pores and increases the density and strength of the soil mass which in turn affects the soil water holding capacity (Hamza \& Anderson, 2005; Nivedita, 1992). High bulk density leads to low water infiltration rate and this can be used as index of soil compaction (Abu-Hamdeh, 2004). Soil compaction may cause such undesirable effects as decreased infiltration of water, restriction of root growth, and increased runoff (Bailey et al., 1988). The plots under conventional ploughing had higher bulk density than the other three tillage practices. At $20-30 \mathrm{~cm}$ depth, the study reviewed that there had been a significant increase in bulk density of the land under across all tillage practices (Table 3 ).

\section{Conclusion}

The inclusion of short term rotational leguminous tree species such as G. sepium and T. candida in crop lands of semi-arid regions is a potential strategy to improve soil fertility and infiltration and increase water retention. $F$. albida has been known to contribute significantly to improved soil fertility and organic matter. However, at four years old, the trees have an undeveloped leaf system which makes the tree unable to influence soil fertility through its shedding of leaves, thus qualifying it as a long term fertility amendment tree. For quick soil fertility and organic matter buildup in the semi-arid region, G. sepium and T. candida can be used as they contribute to organic matter buildup with frequent coppicing.

\section{References}

Abu-Hamdeh, N. (2004). The Effect of Tillage Treatments on Soil Water Holding Capacity and on Soil Physical Properties. Paper Presented at the Conserving Soil and Water for Society: Sharing Solutions. ISCO 13th International Soil Conservation Organization Conference, Brisbane, No. 669, 1-6. 
Arowolo, A. (2007). Alley Farming and Sustainable Agriculture. Paper Presented at the Proceedings of Annual Conference of IRDI Research and Development Network.

Bailey, A., Nichols, T., \& Johnson, C. (1988). Soil Stress State Determination under Wheel Loads. Transactions of the ASAE (USA), 31, 1309-1314.

Biamah, E. (2005). Coping with Drought: Options for Soil and Water Management in Semi-Arid Kenya. Wageningen: Wageningen University and Research Centre.

Biamah, E., Gichuki, F., \& Kaumbutho, P. (1993). Tillage Methods and Soil and Water Conservation in Eastern Africa. Soil and Tillage Research, 27, 105-123. http://dx.doi.org/10.1016/0167-1987(93)90064-V

Cattanio, J. (2012). Leaves Material Decomposition from Leguminous Trees in an Enriched Fallow. Federal University of Pará-UFPA, Brazil: INTECH Open Access Publisher.

Chivenge, P., Murwira, H., Giller, K., Mapfumo, P., \& Six, J. (2007). Long-Term Impact of Reduced Tillage and Residue Management on Soil Carbon Stabilization: Implications for Conservation Agriculture on Contrasting Soils. Soil and Tillage Research, 94, 328-337. http://dx.doi.org/10.1016/j.still.2006.08.006

Diaz, S., Hodgson, J., Thompson, K., Cabido, M., Cornelissen, J., Jalili, A., \& Asri, Y. (2004). The Plant Traits That Drive Ecosystems: Evidence from Three Continents. Journal of Vegetation Science, 15, 295-304. http://dx.doi.org/10.1111/j.1654-1103.2004.tb02266.x

Gicheru, P., Gachene, C., Mbuvi, J., \& Mare, E. (2004). Effects of Soil Management Practices and Tillage Systems on Surface Soil Water Conservation and Crust Formation on a Sandy Loam in Semi-Arid Kenya. Soil and Tillage Research, 75, 173-184. http://dx.doi.org/10.1016/S0167-1987(03)00161-2

Hamza, M., \& Anderson, W. (2005). Soil Compaction in Cropping Systems: A Review of the Nature, Causes and Possible Solutions. Soil and Tillage Research, 82, 121-145. http://dx.doi.org/10.1016/j.still.2004.08.009

Hernanz, J., López, R., Navarrete, L., \& Sanchez-Giron, V. (2002). Long-Term Effects of Tillage Systems and Rotations on Soil Structural Stability and Organic Carbon Stratification in Semiarid Central Spain. Soil and Tillage Research, 66, 129141. http://dx.doi.org/10.1016/S0167-1987(02)00021-1

Imogie, A., Udosen, C., Ugbah, M., \& Utulu, S. (2008). Long Term Effect of Leucaena leucocephala on Soil PhysicoChemical Properties and Fresh Fruit Bunch (FFB) Production of Oil Palm. African Journal of Plant Science, 2, 129-132.

Jaetzold, R., Schmidt, H., Hornetz, B., \& Shisanya, C. (2006). Ministry of Agriculture Farm Management Handbook of Kenya VOL. II-Part C Subpart C1. Nairobi: Ministry of Agriculture.

Lal, R. (2002). Carbon Sequestration in Dryland Ecosystems of West Asia and North Africa. Land Degradation \& Development, 13, 45-59. http://dx.doi.org/10.1002/ldr.477

Li, J., Yang, Q., Li, P., \& Yang, Q. (2009). Experimental Research on Soil-Water Characteristic Curve of Remolded Residual Soils. Electronic Journal of Geotechnical Engineering, 14, 1-12.

Mann, L., Tolbert, V., \& Cushman, J. (2002). Potential Environmental Effects of Corn (Zea mays L.) Stover Removal with Emphasis on Soil Organic Matter and Erosion. Agriculture, Ecosystems \& Environment, 89, 149-166. http://dx.doi.org/10.1016/S0167-8809(01)00166-9

Meskini, V., Mohammadi, M., \& Vanclooster, M. (2014). Predicting the Soil Moisture Retention Curve, from Soil Particle Size Distribution and Bulk Density Data Using a Packing Density Scaling Factor. Hydrology and Earth System Sciences, 18, 4053-4063. http://dx.doi.org/10.5194/hess-18-4053-2014

Nivedita, M. (1992). Effect of Moisture Status and Bulk Density on Germination and Emergence of Pearl Millet, Sorghum and Groundnut on an Alfisol. Hyderabad, India: Andhra Pradesh Agricultural University.

Nyamadzawo, G., Chikowo, R., Nyamugafata, P., Nyamangara, J., \& Giller, K. (2008). Soil Organic Carbon Dynamics of Improved Fallow-Maize Rotation Systems under Conventional and No-Tillage in Central Zimbabwe. Nutrient Cycling in Agroecosystems, 81, 85-93. http://dx.doi.org/10.1007/s10705-007-9154-y

Nyangito, M., Musimba, N., \& Nyariki, D. (2009). Hydrologic Properties of Grazed Perennial Swards in Semiarid Southeastern Kenya. African Journal of Environmental Science and Technology, 3, 26-33.

Nyariki, D., Musimba, N., Ikutwa, C., \& Teka, T. (2004). Dryland Husbandry for Sustainable Development in the Southern Rangelands of Kenya. Addis Ababa: OSSREA.

Osuji, G., Okon, M., Chukwuma, M., \& Nwarie, I. (2010). Infiltration Characteristics of Soils under Selected Land Use Practices in Owerri, Southeastern Nigeria. World Journal of Agricultural Sciences, 6, 322-326.

Powlson, D., Hirsch, P., \& Brookes, P. (2001). The Role of Soil Microorganisms in Soil Organic Matter Conservation in the Tropics. Nutrient Cycling in Agroecosystems, 61, 41-51. http://dx.doi.org/10.1023/A:1013338028454

Rao, M. R., Nair, P. K. R., \& Ong, C. K. (1998). Biophysical Interactions in Tropical Agroforestry Systems. In P. K. R. Nair, \& C. R. Latt (Eds.), Directions in Tropical Agroforestry Research (pp. 3-50). Dordrecht: Springer. http://dx.doi.org/10.1007/978-94-015-9008-2 1 
Salazar, O., Casanova, M., \& Kätterer, T. (2011). The Impact of Agroforestry Combined with Water Harvesting on Soil Carbon and Nitrogen Stocks in Central Chile Evaluated Using the ICBM/N Model. Agriculture, Ecosystems \& Environment, 140, 123-136. http://dx.doi.org/10.1016/j.agee.2010.11.019

Thierfelder, C., \& Wall, P. (2009). Effects of Conservation Agriculture Techniques on Infiltration and Soil Water Content in Zambia and Zimbabwe. Soil and Tillage Research, 105, 217-227. http://dx.doi.org/10.1016/j.still.2009.07.007

Tuller, M., \& Or, D. (2004). Retention of Water in Soil and the Soil Water Characteristic Curve. Encyclopedia of Soils in the Environment, 4, 278-289.

Vanapalli, S., Fredlund, D., \& Pufahl, D. (1999). The Influence of Soil Structure and Stress History on the Soil-Water Characteristics of a Compacted Till. Géotechnique, 49, 143-159. http://dx.doi.org/10.1680/geot.1999.49.2.143

Walkley, A., \& Black, I. (1934). An Estimation of the Degtjareft Method for Determining of Soil Organic Matter and a Proposed Modification of Chromic Acid Titration Method. Soil Science, 37, 29-38. http://dx.doi.org/10.1097/00010694-193401000-00003

Wild, A. (1984). Soil and the Environment: An Introduction. Cambridge: Cambridge University Press.

Zhou, J., \& Yu, J. L. (2005). Influences Affecting the Soil-Water Characteristic Curve. Journal of Zhejiang University Science, 6, 797-804. http://dx.doi.org/10.1631/jzus.2005.A0797 